Original Research Paper

\title{
Effect of Cocoa Pulp Level Mixed With Feed Concentrate on Performance and Blood Metabolite Profiles of Dry-Lot Fattening Bali Steers
}

\author{
${ }^{1}$ Renny Fatmyah Utamy, ${ }^{2}$ Yasuyuki Ishii, ${ }^{1}$ Ambo Ako, ${ }^{1}$ Muhammad Ihsan Andi Dagong, \\ ${ }^{1}$ N. Nahariah, ${ }^{3}$ Purnama Isti Khaerani, ${ }^{4}$ Arung Bandong, ${ }^{4}$ Faisal Asbar and ${ }^{4}$ Ardianto \\ ${ }^{1}$ Department of Animal Production, Faculty of Animal Science, Hasanuddin University, Indonesia \\ ${ }^{2}$ Department of Animal and Grassland Sciences, Faculty of Agriculture, University of Miyazaki, Japan \\ ${ }^{3}$ Post Graduate Program, Agricultural System, Hasanuddin University, Indonesia \\ ${ }^{4}$ Graduate School of Animal Science, Hasanuddin University, Indonesia
}

\author{
Article history \\ Received: 06-09-2021 \\ Revised: 12-10-2021 \\ Accepted: 21-10-2021 \\ Corresponding Author: \\ Renny Fatmyah Utamy \\ Department of Animal \\ Production, Faculty of Animal \\ Science, Hasanuddin \\ University, Indonesia \\ Email: \\ rennyfatmyahutamy198@gmail.com
}

\begin{abstract}
Aim of this study is to evaluate the utilization of cocoa pulp as an alternative feedstuff source for the performance and blood metabolite profiles of dry-lot fattening Bali steers. Nine fattening Bali steers were randomly assigned to experimental diets, composed of three levels of cocoa pulp of 0,5 and $10 \%$ with reducing levels of milled corn composition at 20, 14 and 8\%, designated as ED0 (control), ED1 and ED2, respectively, under a completely randomized design. Herbages, consisted of dwarf napiergrass (Pennisetum purpureum cv. Mott) at $90 \%$ and Indigofera sp. at $10 \%$, were fed at fresh matter basis $60 \%$, with the experimental diet at $40 \%$. Dry Matter Intake (DMI) tended to be higher in ED1 than in ED2 without significant difference $(\mathrm{p}>0.05)$ among treatments. The Average Daily Gain (ADG) decreased from $0.74 \mathrm{~kg} / \mathrm{head} /$ day in ED0 to $0.43 \mathrm{~kg} / \mathrm{head} /$ day in ED2, while that in ED1 did not decrease from ED0. The effect of experimental diets did not differ significantly $(\mathrm{p}>0.05)$ on body performance, hematological or biochemical parameters. The results indicated that the experimental diet did not affect the hematological or biochemical parameters; however, the feedstuff mixed with cocoa pulp at $5 \%$ showed a comparable average daily gain in fattening Bali steers with control.
\end{abstract}

Keywords: Biochemical and Hematological Property, Cocoa Pulp, Experimental Diet, Dry-Lot Fattening

\section{Introduction}

Feed cost represents about $70 \%$ in livestock production cost, the biggest component in livestock farming, which must prepare for feedstuff (Slattery, 2005; IPCC, 2014; Alqaisi et al., 2017. The price of feed fluctuates, depending on market demand and seasons such as the dry period. Moreover, pasture has been turned into settlements. Therefore, to meet the feed nutrition of livestock, farmers require not only additional feed sources for fattening cattle used to grow, produce and reproduce but also forage nutrition (Amsalu and Addisu, 2014).

Agro-industrial by-products and processed agroindustrial wastes are generally available as an alternative source of additional feed because they are quite abundant and cheaper than concentrates. Some researchers suggest that agro-industrial wastes from processed cacao such as cocoa pod husk and cocoa shell could supply the substantial energy requirements of ruminants, including cattle and sheep (Alexander et al., 2008; Alemawor et al., 2009; Adeyina et al., 2010). Additionally, one of the agro-industrial cocoa bean by-products potentially used as feedstuff is cocoa pulp, which is obtained from cacao processing (Rojo-Poveda et al., 2020). Some advantages of cocoa pulp are abundant production, potential nutritional value and feedstuff substitutability.

In Indonesia, especially South Sulawesi, cocoa is an export commodity. On the basis of the statistical data of South Sulawesi in 2019, one of the main commodities exported in 2019 was cocoa/chocolate, occupying $3.93 \%$ (SCSAS, 2018) and in fact, the Government of South Sulawesi is targeting cocoa production up to 276,000 tons/year. Hence, the availability of cocoa by-products (i.e., cocoa pulp) would possibly increase, representing 
sufficient feedstuffs in feed concentrates. Cocoa pulp is obtained when the beans are removed from the pod after harvest. The remaining parts of pod and hust of the cocoa represent between $2 / 3$ and $3 / 4$ of the total weight of the fruit, while they are usually discarded by local farmers after pod processing (Makinde et al., 2019).

Cocoa pulp contains a high sugar content, which can be used as a source of energy for livestock (Schwan and Wheals, 2004; Duarte et al., 2010). Fermented cocoa shell as feed has been used by cattle (Suryanto et al., 2017; Syapridus et al., 2016) and goat and sheep (Zain, 2009). Some research findings suggest that the cocoa pulp has also been used as a feedstuff in sheep concentrate at $15 \%$ (Ako et al., 2019) and has the potential to be used up to $10 \%$ incomplete feed with corn cobs as the fibre source for ruminants (Natsir et al., 2018). However, no studies were conducted on the utilization of cocoa pulp as dry-lot fattening Bali steers. The previously research was aimed to show the potential of cocoa pulp as a ruminant feed for both sheep and cattle.

Blood components are important for maintaining the whole body of livestock. The main function of blood is to deliver the oxygen needed by cells throughout the animal body. Blood also supplies body tissues with nutrients, transports metabolic wastes and contains several ingredients that protect the body from various diseases. Generally, the dietary pattern may be more useful to understand the influence of diets on the metabolic health of livestock. Furthermore, the relationship between dietary patterns and metabolite profiles, such as blood metabolite profiles is required to acquire livestock performance. Therefore, the objectives of this study were to evaluate the effect of mixed levels of cocoa pulp in the experimental diets on the performance and blood metabolite profiles of fattening Bali steers.

\section{Materials and Methods}

\section{Experimental Die Formulation}

Herbages as a main source of feed consisted of dwarf napier grass at $90 \%$ and Indigofera sp. at $10 \%$, whereas feed concentrates as an experimental diet consisted of cocoa pulp, rice bran, coconut cake meal, shrimp waste meal, corn epidermis, milled corn, molasses and minerals. The ratio of herbages and experimental diets was fixed among treatments to be provided at 60 and $40 \%$, respectively. The experimental diets were divided into three levels of cocoa pulp at 0,5 and $10 \%$ as dry matter basis with substituting milled corn levels at 20, 14 and $8 \%$, respectively, in ED0, ED1 and ED2. The feedstuff composition of the experimental diets is shown in Table 1. The chemical contents of experimental diets were analysed at Animal Product Technology, Faculty of Animal Science, Hasanuddin University, Makassar.
Composition of cocoa pulp consisted of $7.00 \%$ dry matter, $7.55 \%$ crude protein, $0.49 \%$ crude fat and $7.71 \%$ crude fibre and that of milled corn, $86 \%$ dry matter, $9 \%$ crude protein, $2 \%$ crude fibre and $4 \%$ crude fat. Furthermore, as the quality of the experimental diets, chemical properties and phytochemical components were analysed.

The chemical composition of the experimental diets was determined for the moisture content by oven-drying at $105^{\circ} \mathrm{C}$ based on the INS (1992) No. 01-2891-1992; the total Nitrogen $(\mathrm{N})$ content, by the Kjeldahl procedure (AOAC, 1990); the percentage of crude protein, calculated as total $\mathrm{N}$ $\times$ 6.25; crude fibre, by INS (1992) No. 01-2891-1992; and ash, by heating at $600^{\circ} \mathrm{C}$ (AOAC, 1990). Flavonoid and theobromine composition of the experimental diets was determined using ultraviolet-visible spectrophotometry (Bojić et al., 2013) and the antioxidant composition, by the diphenyl-2-picrylhydrazyl method (Fitriana et al., 2016).

\section{Site Description and Feed Trial}

The experiment was conducted in Gowa Regency (South Sulawesi, Indonesia). Three experimental diets contained three replications, allocated into three heads and thus, nine heads of dry-lot fattening Bali steers were allocated in total. The experimental diets were fed once at 7:00 a.m. and herbages were fed twice a day at 10:00 a.m. and 4:00 p.m. The experimental diet was fed at $3 \%$ dry matter of body weight of steers. Drinking water was given ad libitum.

\section{Performance of Dry-Lot Fattening Bali Steers}

Performance of dry-lot fattening Bali steers, such as body weight gain $(\mathrm{kg})$, chest circumference $(\mathrm{cm})$, body length $(\mathrm{cm})$ and shoulder height $(\mathrm{cm})$, were taken after 2 weeks of feed adaptability as the initial day (D-0). At the end of the research, data were also collected as the final day (D-85).

Weight gain, chest circumference, body length and a shoulder height of fattening Bali steers were measured on the initial day, days 25, 55 and 85 , designated as D-0, D-25, D-55 and D-85, respectively. Dry Matter Intake (DMI), Average Daily Gain (ADG) and Feed Conversion Rate (FCR) were calculated as shown in Eq. 1, 2 and 3, respectively.

$\operatorname{DMI}(\mathrm{kg} / \mathrm{head} /$ day $)=$

(Total amount of feed consumed - Re maining feed) per day

$$
\begin{aligned}
& A D G(\mathrm{~kg} / \mathrm{head} / \text { day }) \\
& =\frac{\text { Final body weight }(\mathrm{kg})-\text { Initial body weight }(\mathrm{kg})}{\text { Experimental period }(\text { day })} \\
& F C R(\mathrm{~kg} / \mathrm{kg})=\frac{\text { Amount of feed fed }(\mathrm{kg})}{\text { Experimental period }(\text { day })}
\end{aligned}
$$




\section{Blood Metabolite Profiles of Fattening Bali Steers}

Blood samples of Bali steers were collected in EDTA tubes for each animal on D-0, D-25, D-55 and D-85 to determine hematological parameters such as Red Blood Cell (RBC) count, White Blood Cell (WBC) count, Hemoglobin $(\mathrm{Hb})$, and Hematocrit $(\mathrm{Ht})$. The percentages of RBC and WBC counts were determined by hemocytometry and $\mathrm{Hb}$ and $\mathrm{Ht}$, by a hemoglobinometer and a microhematocrit centrifuge, respectively. Blood samples were analyzed at the Laboratory of Animal Physiology, Faculty of Animal Science, Hasanuddin University, Makassar, South Sulawesi, Indonesia.

Biochemical parameters of blood samples, such as glucose, cholesterol and blood urea, were determined by hexokinase, CHOD-PAP and enzymatic-GLDH, respectively, by the instruments from Thermo Scientific Indiko, Germany. Additionally, alanine Aminotransferase (ALT) and aspartate Aminotransferase (AST) were determined by International Federation of Clinical Chemistry, IFCC without pyridoxal phosphate (incubation at $37^{\circ} \mathrm{C}$ ). The biochemical parameters were analysed at the Public Health Laboratory (Makassar, South Sulawesi, Indonesia).

\section{Statistical Analysis}

The data obtained were analysed using SPSS software for Windows ver. 16.0 (Chicago, IL, USA). The experiment was carried out according to a completely randomized design with three treatments and three replications and the difference among treatments was tested by the least significant difference at the $5 \%$ level.

\section{Results}

\section{Chemical Analysis of the Experimental Diets}

The chemical contents of proximate and phytochemical components in the experimental diets were measured (Table 2). As for the proximate components, the moisture content increased from $11.48 \%$ (ED0) to $42.88 \%$ (ED2) along with increasing cocoa pulp level from 0 to $10 \%$, due to high moisture content (7\% dry matter) in cocoa pulp. Similarly, crude protein, crude fibre and ash contents tended to increase, while fat and nitrogen-free extract contents tended to decrease, with increasing levels of the cocoa pulp as well as reducing levels of milled corn.

\section{Effect of the Experimental Diets on Performance of Dry-Lot Fattening Bali Steers}

Performance of dry-lot fattening Bali steers fed in vivo to three levels of experimental diets mentioned above were determined for DMI, ADG and FCR, which were tested by statistical analysis at 5\% level (Table 3 ). With increasing levels of cocoa pulp as well as reducing levels of milled corn, DMI tended to decrease from $2.81 \%$ (ED0) to $2.37 \%$ (ED2) without significant difference among treatments, while ADG decreased $(\mathrm{P}<0.05)$ from $0.74 \%$ (ED0) to $0.43 \%$ (ED2) and thus, FCR tended to increase from 4.53 (ED0) to 6.56 (ED2).

Performance of dry-lot fattening Bali steers with respect to body size parameters, such as weight gain, chest circumference, body length and shoulder height is presented in Fig. 1. The experimental diet did not significantly affect $(p>0.05)$ neither on weight gain (Fig. 1A), chest circumference (Fig. 1B), body length (Fig. 1C), nor on shoulder height (Fig. 1D). In all the experimental diets, body weight increased from D-0 to D-85, while it showed stagnant on D-55 and turned to increase on D-85 in ED2 and tended to run through the higher values from D-25 to D-85 in ED1, compared with the other diets.

The chest circumference in ED1 tended to increase faster compared with that in ED0 and ED2 from D-25 to D-85. The body length at all experimental diets tended to be inconsistent over time; however, the body length in ED1 tended to be high on D-55. The shoulder height of ED1 tended to be higher than that of the other diets from D-25 to D-85.

\section{Effect of the Experimental Diets on Blood Metabolite Parameters in Dry-Lot Fattening Bali Steers}

The experimental diet did not significantly affect the profile of either the hematological or the biochemical parameters ( $>>0.05)$ (Table 4) and all the hematological and biochemical parameters entered to the normal threshold of cattle. As for the hematological parameters, RBC count tended to increase along with additional levels of cocoa pulp in the experimental diets. Although the high value of WBC can be used as a parameter of disturbed health of cattle, it did not affect the cattle performance of dry-lot fattening steers, or trends in ADG in the current study (Fig. 1A).

Although blood $\mathrm{Hb}$ and $\mathrm{Ht}$ values also fluctuated with the experimental diets, blood $\mathrm{Hb}$ and $\mathrm{Ht}$ values were still within the normal threshold. $\mathrm{Hb}$ in $\mathrm{RBC}$ carries oxygen throughout the body for metabolic processes and provides the colour of red blood cells and high level of $\mathrm{Hb}$ increases the oxygen supply to tissue; therefore, the metabolic processes in the animal tissues run optimally. The experimental diets affected different trends in biochemical properties, which did not differ significantly among diets, ranging from increasing trend in blood urea levels, decreasing trend in cholesterol and ALT levels and fluctuating trend in glucose and blood AST levels along with additional levels of cocoa pulp (Table 4). 


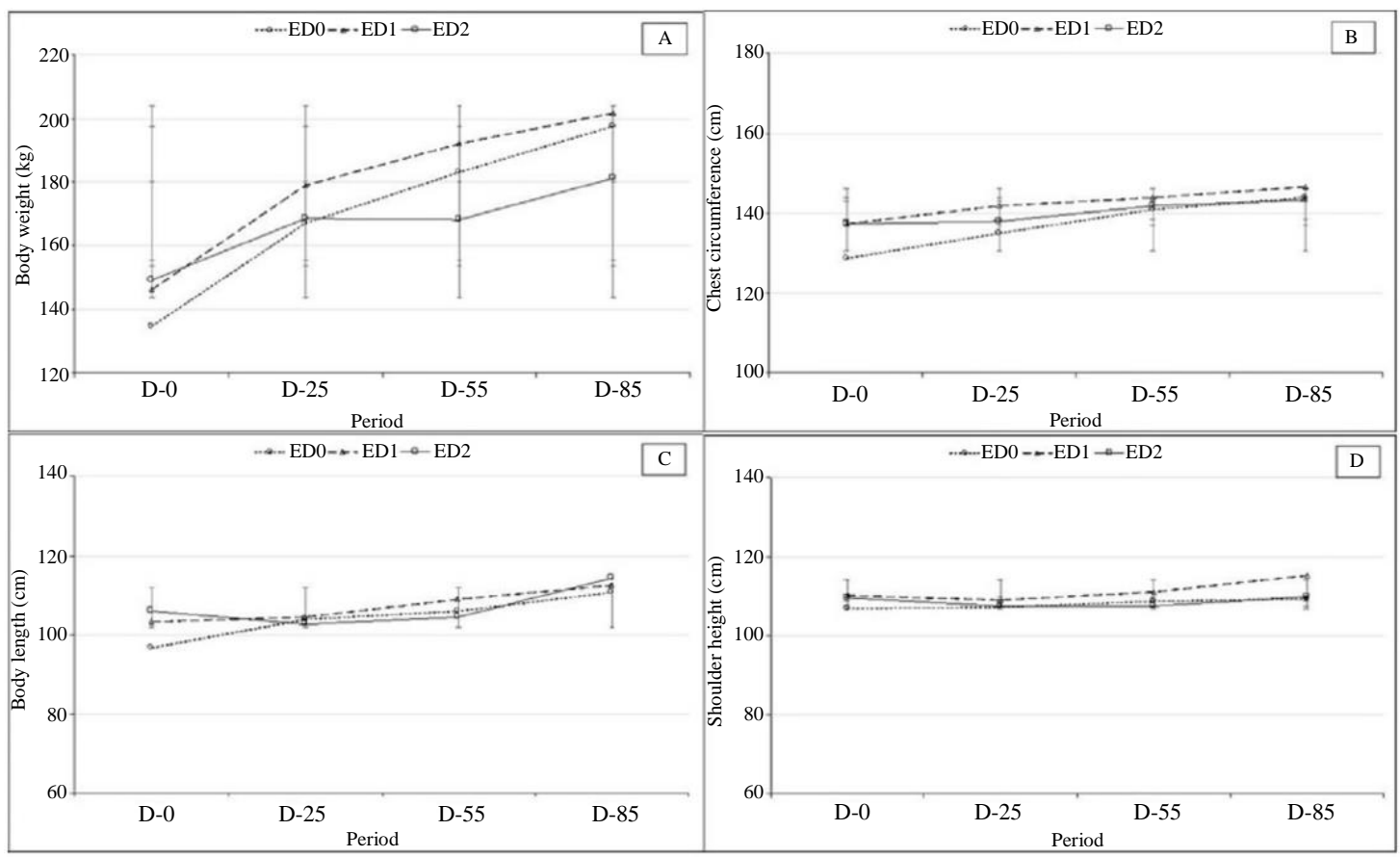

Fig. 1: Performance of dry-lot fattening Bali steers: (A) body weight gain; (B) chest circumference; (C) body length; (D) shoulder height. The experimental diets, ED0, ED1 and ED2 mean the feedstuffs mixed with 0, 5 and 10\% levels of cocoa pulp, respectively

Table 1: The feedstuff composition of experimental diets for the performance of dry-lot fattening Bali steers

\section{Experimental diet (\% cocoa pulp)}

\begin{tabular}{llll} 
Feedstuff $(\%)$ DM basis & ED0 $(0 \%)$ & ED1 $(5 \%)$ & ED2 $(10 \%)$ \\
\hline Cocoa pulp & 0 & 5 & 10 \\
Rice bran & 20 & 20 & 20 \\
Coconut cake meal & 20 & 20 & 20 \\
Shrimp waste meal & 20 & 21 & 22 \\
Corn epidermis & 17 & 17 & 17 \\
Milled corn & 20 & 14 & 8 \\
Molasses & 2 & 2 & 2 \\
Mineral & 1 & 1 & 1 \\
Total & 100 & 100 & 100 \\
\hline
\end{tabular}

Table 2: Chemical content of experimental diets for the performance of dry-lot fattening Bali steers

\begin{tabular}{|c|c|c|c|}
\hline \multirow[b]{2}{*}{ Parameter } & \multicolumn{3}{|c|}{ Experimental diet (\% cocoa pulp) } \\
\hline & ED0 $(0 \%)$ & $\operatorname{ED} 1(5 \%)$ & $\mathrm{ED} 2(10 \%)$ \\
\hline \multicolumn{4}{|c|}{ Proximate component $(\%)$} \\
\hline Moisture content & $11.48 \pm 0.33$ & $33.43 \pm 0.86$ & $42.88 \pm 2.56$ \\
\hline Crude protein & $12.43 \pm 0.64$ & $12.88 \pm 0.44$ & $13.76 \pm 0.24$ \\
\hline Crude fat & $5.37 \pm 0.43$ & $3.79 \pm 0.46$ & $3.89 \pm 0.20$ \\
\hline Crude fiber & $17.14 \pm 0.32$ & $17.14 \pm 1.65$ & $20.00 \pm 1.74$ \\
\hline Ash & $21.20 \pm 0.79$ & $24.13 \pm 0.77$ & $22.26 \pm 1.11$ \\
\hline Nitrogen-free extract & $43.86 \pm 1.16$ & $42.06 \pm 1.12$ & $40.09 \pm 1.09$ \\
\hline \multicolumn{4}{|c|}{ Phytochemical component (\%) } \\
\hline Flavonoid & $0.19 \pm 0.00$ & $0.16 \pm 0.00$ & $0.15 \pm 0.00$ \\
\hline Theobromine & $0.34 \pm 0.01$ & $0.55 \pm 0.00$ & $0.60 \pm 0.00$ \\
\hline Antioxidant & $77.09 \pm 7.69$ & $47.68 \pm 4.29$ & $47.11 \pm 7.55$ \\
\hline
\end{tabular}

Data were presented as means \pm standard deviation. $\S E D 0=$ the experimental diets without cocoa pulp; ED1 = the experimental diets with 5\% of cocoa pulp; and ED2 $=$ the experimental diets with 10\% of cocoa pulp. Nitrogen Free Extract $=100 \%$ DM - Crude Protein - Crude Fat - Crude Fiber - Ash 
Table 3: Dry matter intake, daily body weight gain and feed consumption rate of dry-lot fattening Bali steer

\begin{tabular}{llll} 
& Experimental diet (\% cocoa pulp) & \\
Parameter & ED0 $(0 \%)$ & ED1 $(5 \%)$ & ED2 $(10 \%)$ \\
\hline DMI (kg/head/day) & $2.81 \pm 0.09$ & $2.77 \pm 0.92$ & $2.37 \pm 0.44$ \\
ADG (kg/head/day) & $0.74 \pm 0.10^{\mathrm{a}}$ & $0.70 \pm 0.14^{\mathrm{ab}}$ & $0.43 \pm 0.21^{\mathrm{b}}$ \\
FCR & $4.53 \pm 2.02$ & $5.84 \pm 3.10$ & $6.56 \pm 2.45$ \\
\hline
\end{tabular}

Data were presented as means \pm standard deviation. Values with superscripts in the same row is differ significantly $(\mathrm{P}<0,05)$. ns $=$ not significant $(\mathrm{P}>0.05)$. $\mathrm{DMI}=$ Dry matter intake; $\mathrm{DBWG}=$ Daily body weight gain $; \mathrm{FCR}=$ Feed Consumption Rate. Experimental diet refers to Table 1

Table 4: Blood metabolite parameters of dry-lot fattening Bali steers

\begin{tabular}{|c|c|c|c|}
\hline \multirow[b]{2}{*}{ Parameter } & \multicolumn{2}{|c|}{ Experimental diet (\% cocoa pulp) } & \multirow[b]{2}{*}{ ED2 $(10 \%)$} \\
\hline & ED0 $(0 \%)$ & $\operatorname{ED} 1(5 \%)$ & \\
\hline \multicolumn{4}{|l|}{ Hematological $^{\dagger}$} \\
\hline $\mathrm{RBC}$ count $\left(10^{6} / \mathrm{mm}^{3}\right)$ & $4.81 \pm 7.86$ & $5.34 \pm 3.51$ & $5.37 \pm 3.58$ \\
\hline WBC count $\left(10^{3} / \mathrm{mm}^{3}\right)$ & $9.43 \pm 0.95$ & $9.78 \pm 1.94$ & $9.60 \pm 1.10$ \\
\hline $\mathrm{Hb}(\mathrm{g} / \mathrm{dL})$ & $8.60 \pm 0.92$ & $8.40 \pm 0.92$ & $9.60 \pm 1.35$ \\
\hline $\mathrm{Ht}(\%)$ & $28.00 \pm 2.00$ & $31.67 \pm 2.52$ & $32.00 \pm 4.58$ \\
\hline \multicolumn{4}{|l|}{ Biochemical ${ }^{\star}$} \\
\hline Glucose (mg/dL) & $42.33 \pm 2.52$ & $42.67 \pm 2.31$ & $38.00 \pm 7.00$ \\
\hline Cholesterol (mg/dL) & $161.00 \pm 9.17$ & $148.00 \pm 14.42$ & $126.67 \pm 45.45$ \\
\hline Blood urea (mg/dL) & $22.33 \pm 2.08$ & $22.00 \pm 3.00$ & $28.00 \pm 4.00$ \\
\hline $\operatorname{ALT}(\mathrm{U} / \mathrm{L})$ & $59.33 \pm 8.62$ & $55.33 \pm 6.66$ & $45.67 \pm 3.21$ \\
\hline AST (U/L) & $80.67 \pm 7.63$ & $74.67 \pm 7.09$ & $81.00 \pm 6.93$ \\
\hline
\end{tabular}

†Laboratory of Animal Physiology, Faculty of Animal Science, University of Hasanuddin, Makassar, South Sulawesi, Indonesia, 2018. $\$$ Public Health Laboratory, Makassar, South Sulawesi, Indonesia, 2018. RBC = Red Blood Cell; WBC = White Blood Cell; Hb = Haemoglobin; and $\mathrm{Ht}=$ Haematocrit. ALT = Alanine Aminotransferase; AST = Aspartate Aminotransferase . Experimental diet refers to Table 1

\section{Discussion}

Crude protein contents ranging in $12.4-13.8 \%$ in the present diets are adequate for optimal microbial protein synthesis (Hume et al., 1970), although if this level drops below $7 \%$, the rumen microorganisms cannot break down the feed efficiently and addition protein supplements need to be added. The whole experimental diets in ED0 to ED2 sufficiently meet the nutritional needs of cattle according to the Indonesian National Standard 2017 No. 3148-2. A nutritionally balanced diet, including sufficient nitrogen and rumen degradable protein must be provided to maximize bacterial fermentation, feed intake and energy digestibility in feeding to ruminants (Matthews et al., 2019).

As for the phytochemical components, the flavonoid and antioxidant contents decreased with adding cocoa pulp, while the mixed level of cocoa pulp in a range of $5-10 \%$ affected these two phytochemical components negligibly. Flavonoids are used to be correlated with their antioxidant activities pharmacologically (Gryglewski et al., 1987). Providing 5\% level cocoa pulp (ED1) to experimental diets containing flavonoids and antioxidants is expected to improve the meat quality, especially related to health issues. According to Heim et al. (2002), flavonoids are polyphenol compounds that are antioxidants or free radical scavengers, have anti-inflammation properties and prevent DNA damage in animal cells (Table 2).

In contrast, the theobromine content increased along with additional levels of cocoa pulp to reach the highest level in ED2 (Table 2). Theobromine content can affect the following disorders: Abnormal spermatozoa morphology, emptying of Sertoli cells, imperfect fetal growth, weight loss, miscarriage and animal death. Furthermore, providing cocoa pods in sheep and goat feed containing theobromine antinutrients can reduce the consumption of dry matter live weight gain (Alexander et al., 2008).

Neither DMI nor ADG did not decrease from ED0 to ED1, while decreased substantially from ED1 to ED2, possibly due to the highest percentage of theobromine in the diet, ED2, since (Alexander et al. 2008) argued that the high percentage of theobromine in the feed formulation could inhibit the growth of rumen microbes and decrease the ability to digest fiber. Therefore, $20 \%$ crude fibre level in ED2 may lead to intricate rumen-microbe digestion, According to Mahyuddin (1995) live weight gain began to decline at $37 \%$ of cocoa shell (or $15 \%$ of the ration). At this concentration, the ration contains 0.24 percent theobromine, may contribute to lower metabolizable energy consumption. Drop of DMI in ED2 may be related with the highest fibre content among treatments, since the increase in crude fibre results in lowering animal productivity.

According to (Ako et al 2019), the use of $10 \%$ cocoa 
pulp in the complete feed formulation containing different sources of herbages, either rice straws, corn cobs or soybean straws, promotes the performance of local goats. Although the experimental diet did not significantly affect DMI, DMI is usually used as an indicator of the level of diet palatability. The provision of exceeding $5 \%$ level of cocoa pulp as feedstuff in the feed concentrate could decrease the palatability of concentrate feed.

Similar to DMI, ADG decreased substantially from ED1 to ED2, while the decrease in ADG from ED0 to ED1 was negligible (Table 3). The current ADG levels in ED0 and ED1 were still higher, compared with the previous study on male Bali cattle, where the cattle were fattened with ad libitum field grass and $1 \%$ concentrates to reach $0.69-0.72 \mathrm{~kg} /$ day ADG.

FCR is feeding conversion to determine the amount of feed converted into body weight gain and is used as an indicator in feed efficiency. As stated by (McCrickerd and Forde, 2016), FCR affected by palatability depends on several factors such as feed appearance, feed shape, door, taste and texture of the diet. In the current study, FCR increased steadily from $4.53,5.84$ to 6.56 along with additional levels of cocoa pulp from 0,5 to $10 \%$, respectively, which was more efficient in FCR compared with 7.32 in the previous study (Melati et al., 2019). Increase in FCR means the increase in feeding cost paid by farmers and animal weight gain is inversely proportional to the FCR value. Therefore, cocoa pulp feeding to fattening Bali steers could be provided within 5\% level.

The animal performance of dry-lot fattening Bali steers in ED1 tended to give the best results compared with ED0 and ED2, which was derived from the following mechanisms: The chemical composition of the experimental diets in ED1 being better, showing higher palatability associated with DMI and the higher ADG (Table 3). The experimental diets in the current study followed the fattening cattle feed standard enacted by the Indonesian National Standard. Additionally, consumption is an important factor in determining ruminant productivity and animal body size (Aregheore, 2000). Chaokaur et al. (2015) stated that the higher the level of feeding, the higher the daily gain of Brahman cattle. Body weight gain generally increases due to the capacity of the digestive tract (Heryiani et al., 2020), unless the feeding level is limited. Food nutrients are converted by the digestive system into simpler chemicals that can be absorbed and used as energy (Heryani et al., 2020) However, a shorter digesta retention period in smaller herbivores may limit the nutrients availability (Ramzinski and Weckerly, 2007)

Increased levels of RBC count indicate that the oxygen content in the blood may increase, which has a positive impact on the body's metabolic activity. The RBC count in cattle is ranging in 3.8-5.7 million $/ \mathrm{mm}^{3}$ (Utama, 2001), 5.49 million $/ \mathrm{mm}^{3}$ (Adam et al., 2015) and 6.33-8.89 million $/ \mathrm{mm}^{3}$, which tends to be higher than in the current study where the RBC count was still within the normal threshold. The WBC count of fattening Bali steers maintained within 9.43-9.78 thousand $/ \mathrm{mm}^{3}$ (Table 4).

The blood glucose level found highest in ED1 entered lower value than the previous report (Tahuk et al., 2018), while higher than the other (Kamal et al. 2016). Animal feed is one of the factors that affect the level of blood glucose content, since (Tahuk et al., 2018) stated that feed for energy consumption is very important to determine the level of blood glucose. Cocoa pulp, containing glucose at $214.24 \mathrm{~g} / \mathrm{L}$, fructose at $10.6 \mathrm{~g} / \mathrm{L}$ and sucrose at $107.6 \mathrm{~g} / \mathrm{L}$, has the potential for use as a feedstock for diet energy (Gyedu, 2001). Although the glucose levels in the current study were lower than the previous studies, they were still within the normal threshold of 43-100 mg/dL (Mitruka and Rawnsley, 1977. Furthermore, the presence of flavonoid content as an antioxidant in cocoa pulp maintains blood glucose stability, stating (Akhlaghi and Bandy, 2009) that the antioxidant activity of flavonoid compounds can capture free radicals to protect pancreatic $\beta$-cells. This protection mechanism plays an important role in preventing damage and consistently maintaining insulin production in the animal body.

The blood cholesterol levels tended to decrease along with the additional levels of cocoa pulp, showing highest cholesterol level found in ED0 (Table 4), in which the level was similar to the previous study (Suharti et al., 2009), who stated that the range of cholesterol in cattle (i.e., $159.75-193.25 \mathrm{mg} / \mathrm{dL}$ ) was lower than in dairy cows (Faza et al., 2017) (i.e., 221.18-250.16 mg/dL). The value of blood cholesterol in the current study was still within the normal threshold value of $80-180 \mathrm{mg} / \mathrm{dL}$. The high cholesterol levels in ED0 may be due to the highest crude fat level, compared with ED1 and ED2 (Table 2), since the feed fat level can increase the total cholesterol levels in the blood (Sejrsen et al., 2006). However, the present experimental diets did not result in changes in fat metabolism in the rumen. The blood cholesterol in the experimental diets containing cocoa pulp results in reducing the content, compared with control.

The blood urea levels tended to increase from ED1 to ED2. The levels of urea in ED0 and ED1 were lower than that of the previous study, showing $24.11 \mathrm{mg} / \mathrm{dL}$ (Tahuk et al., 2018). Blood urea is used as an indicator to assess the adequacy of animal feed protein during the fattening period. If the ammonia level in the rumen is high, the absorption of ammonia carried to the liver will be excessive. The enhanced concentration of blood protein urea will be proportional to the availability of feed protein (Getahun et al., 2019).

The blood ALT levels tended to decrease along with additional levels of cocoa pulp, showing that the experimental diets containing cocoa pulp reduced blood ALT levels, compared with the control (ED0). This is probably due to the inadaptability of the experimental 
diets and additionally, the examined steers experienced changes in feeding patterns, triggering a level of stress on them. Xie et al. (2020) stated that the liver and kidney tissues can experience disturbed metabolism if there is a change in feeding patterns. Furthermore, Picard et al. (2018) mentioned that apart from feeding patterns, stress can affect the metabolic processes of livestock, where the mitochondria work excessively to produce excess energy, resulting in cell damage in blood. Table 4 shows that the value of ALT levels was 45.67-59.33 U/L, which entered still normal range, according to the previous study, ranging around 20-76.8 U/L (Mitruka et al., 1997).

AST can be used as an indicator of the health of liver function. The liver is the center of carbohydrate, protein, fat and mineral metabolisms, all of these related to feedstuff. Feed contaminated with hazardous materials will generate metabolic damage in the liver (Ali et al., 2019). On the basis in Table 4, AST values in this study fluctuated in the range of 58-83 U/L, which entered still within the normal threshold for cattle, according to the previous study, finding AST value around 8.5-93 U/L (Mitruka et al., 1997).

The present experimental diets provided in fattening steers meet the Indonesian National Standard and did not jeopardize either the hematologic or biochemical functions of fattening Bali steers. Therefore, the present experimental diet was suitable for consumption of the steers.

\section{Conclusion}

The results suggest that the experimental diets mixed with 5 and $10 \%$ levels of cocoa pulp did not affect the hematologic or biochemical parameters of fattening Bali steers. However, the mixed level of cocoa pulp with concentrates should be recommended at the level of $5 \%$, due to no decrease in average daily gain or dry matter intake from control. In the future, feeding 5\% cocoa pulp to dry-lot fattening Bali steers could be implemented with reducing rate of milled corn and reducing wastes as using by products from the cocoa industry.

\section{Acknowledgment}

The authors would like to express their gratitude to The Ministry of Research, Technology and Higher Education of Indonesia through Institution of Research and Extension of Hasanuddin University for funding this study. The authors would like to express sincere thanks to Livestock Farmer of Bunga Teratai for providing a livestock farm and PT. Mars Symbio Science Indonesia for providing cocoa pulp.

\section{Declaration of Interest Statement}

We certify that there is no conflict of interest with any financial organization regarding the material discussed in the manuscript.

\section{Funding Information}

This study was funded by The Ministry of Research, Technology and Higher Education of Indonesia.

\section{Author's Contributions}

Renny Fatmyah Utamy and Ambo Ako: Conceived and designed the experiments, performed the field experiments, performed analyzed data, wrote the paper

Yasuyuki Ishii: Experiments performed analyzed data, wrote the paper

Muhammad Ihsan Andi Dagong: Performed the field experiments, performed analyzed data, wrote the paper.

N. Nahariah: Performed phytochemical analysis.

Purnama Isti Khaerani, Arung Bandong and Ardianto: Performed the field experiments.

Faisal Asbar: Performed the field experiments, performed hematology analyzsis

\section{Ethics}

This article is original and contains unpublished material. The corresponding author confirms that all of the other authors have read and approved the manuscript and no ethical issues involved.

\section{References}

Adam, M., Lubis, T. M., Abdyad, B., Asmilia, N., Muttaqien, M., \& Fakhrurrazi, F. (2015). Jumlah eritrosit dan nilai hematokrit sapi aceh dan sapi bali di kecamatan leumbah seulawah kabupaten aceh besar (Total Erythrocytes Count and Haematocrit Value of Aceh and Bali Cattle in Leumbah Seulawah, Aceh Besar). Jurnal Medika Veterinaria, 9(2). doi.org/10.21157/j.med.vet..v9i2.3810

Adeyina, A. O., Apata, D. F., Annongu, A. A., Olatunde, O. A., Alli, O. I., \& Okupke, K. M. (2010). Performance and physiological response of weaner rabbits fed hot water treated cocoa bean shell-based diet. Res J Anim Vet Sci, 5, 53-7.

http://www.aensiweb.net/AENSIWEB/rjavs/rjavs/20 10/53-57.pdf

Akhlaghi, M., \& Bandy, B. (2009). Mechanisms of flavonoid protection against myocardial ischemiareperfusion injury. Journal of molecular and cellular cardiology, 46(3), 309-317. doi.org/10.1016/j.yjmcc.2008.12.003

Ako, A., Mujnisa, A., \& Natsir, A. (2019, March). Performance of local goat fed on complete feed containing cocoa pulp with different fiber sources. In IOP Conference Series: Earth and Environmental Science (Vol. 247, No. 1, p. 012004). IOP Publishing.https://iopscience.iop.org/article/10.1088 /1755-1315/247/1/012004/meta 
Alemawor, F., Dzogbefia, V. P., Oddoye, E. O., \& Oldham, J. H. (2009). Enzyme cocktail for enhancing poultry utilisation of cocoa pod husk. Scientific Research and Essays, 4(6), 555-559.

https://academicjournals.org/journal/SRE/articleabstract/0A4ED3517179

Alexander, J., Anderson, H. C., Bernhoft, A., Brimer, L., Cottrill, B. (2008). Theobromine as undesirable substance in animal feed: Scientific opinion of the panel on contaminants in the food chain. European Food Safety Authority Journal. 725, 1-66. doi.org/10.2903/j.efsa.2008.725

Ali, H., Khan, E., \& Ilahi, I. (2019). Environmental chemistry and ecotoxicology of hazardous heavy metals: Environmental persistence, toxicity and bioaccumulation. Journal of chemistry, 2019 doi.org/10.1155/2019/6730305

Alqaisi, O., Ndambi, O. A., \& Willmiams, R. B. (2017). Time series livestock diet optimization: Cost-effective broiler feed substitution using the commodity price spread approach. Agricultural and Food Economics, 5, 25. doi.org/10.1186/s40100-017-0094-9

Amsalu, T., \& Addisu, S. (2014). Assessment of grazing land and livestock feed balance in Gummara-Rib Watershed, Ethiopia. Current Agriculture Research, 2(2). doi.org/10.12944/CARJ.2.2.08

AOAC. (1990). "Officials method of analysis", 13th ed., Washington, DC: Association of Official Analytical Chemist.

Aregheore, E. M. (2000). Chemical composition and nutritive value of some tropical by-product feedstuffs for small ruminants-in vivo and in vitro digestibility. Animal feed science and technology, 85(1-2), 99-109. doi.org/10.1016/S0377-8401(00)00123-1

Bojić, M., Simon Haas, V., Šarić, D., \& Maleš, Ž. (2013). Determination of flavonoids, phenolic acids and xanthines in mate tea (Ilex paraguariensis St.-Hil.). Journal of analytical methods in Chemistry, 2013. doi.org/10.1155/2013/658596s

Chaokaur, A., Nishida, T., Phaowphaisal, I., \& Sommart, K. (2015). Effects of feeding level on methane emissions and energy utilization of Brahman cattle in the tropics. Agriculture, Ecosystems \& Environment, 199, 225-230. doi.org/10.1016/j.agee.2014.09.014

Duarte, W. F., Dias, D. R., Oliveira, J. M., Teixeira, J. A., e Silva, J. B. D. A., \& Schwan, R. F. (2010). Characterization of different fruit wines made from cacao, cupuassu, gabiroba, jaboticaba and umbu. LWT-Food Science and Technology, 43(10), 1564-1572. doi.org/10.1016/j.lwt.2010.03.010

Faza, A. F., Soejono, C. B., Sayuthi, S. M., \& Santoso, S. A. B. (2017). Profil lemak darah sapi perah laktasi akibat suplementasi baking soda dalam pakan. Jurnal Sain Peternakan Indonesia, 12(4), 353-359. doi.org/10.31186/jspi.id.12.4.353-359
Fitriana, W. D., Ersam, T., Shimizu, K., \& Fatmawati, S. (2016). Antioxidant activity of Moringa oleifera extracts. Indonesian Journal of Chemistry, 16(3), 297-301. https://pdfs.semanticscholar.org/6bfe/e00d35812e31 6cc0b681f70a6da4269fb5be.pdf

Getahun, D., Getabalew, M., Zewdie, D., Alemneh, T., \& Akeberegn, D. (2019). Urea metabolism and recycling in ruminants. BJSTR, 20, 14790-14796.

Gryglewski, R. J., Korbut, R., Robak, J., \& Święs, J. (1987). On the mechanism of antithrombotic action of flavonoids. Biochemical pharmacology, 36(3), 317-322. doi.org/10.1016/0006-2952(87)90288-7

Gyedu, E. (2001). Cocoa pulp juice (sweatings) as a potential raw material for the development of soft drink. Journal of the Ghana Science Association, 3(3), 57-61. https://www.ajol.info/index.php/jgsa/article/view/ 17767

Heim, K. E., Tagliaferro, A. R., \& Bobilya, D. J. (2002). Flavonoid antioxidants: Chemistry, metabolism and structure-activity relationships. The Journal of nutritional biochemistry, 13(10), 572-584. doi.org/10.1016/S0955-2863(02)00208-5

Heryiani, L. G. S., Susari, N. N. W, Syamadina, L. P., \& Nareswari. (2020). Anatomical and morphometric study of small and large intestine of bali cattle. Journal of Veterinary and Animal Sciences, 3(2): 86-94. https://doi.org/10.24843/JVAS.2020.v03.i02.p04

Hume, I. D., Moir, R. J., \& Somers, M. (1970). Synthesis of microbial protein in the rumen. I. Influence of the level of nitrogen intake. Australian Journal of Agricultural Research, 21(2), 283-296. doi.org/10.1071/AR9700283

INS. (1992). “Cara Uji Makanan dan Minuman”. Jakarta, The Standarization Council of Indonesia. Indonesian National Standard.

IPCC. (2014). Summary for Policymakers in Climate Change 2013. The Physical Science Basis: Working Group I Contribution to the Fifth Assessment Report of the Intergovernmental Panel on Climate Change, Cambridge: Cambridge University Press. Intergovernmental Panel on Climate Change.

Kamal, R., Dutt, T., Patel, M., Dey, A., Chandran, P. C., Bharti, P. K., \& Barari, S. K. (2016). Behavioural, biochemical and hormonal responses of heat-stressed crossbred calves to different shade materials. Journal of Applied Animal Research, 44(1), 347-354. doi.org/10.1080/09712119.2015.1074076

Mahyuddin, P. (1995). The nutritive value of cocoa shell in ruminants. In: International Seminar on Tropical Animal Production (ISTAP). pp. 155-160. https://journal.ugm.ac.id/istapproceeding/article/vie w/32629/19696 
Makinde, O. J., Okunade, S. A., Opoola, E., Sikiru, A. B., Ajide, S. O., \& Elaigwu, S. (2019). Exploration of Cocoa (Theobroma cacao) By-Products as Valuable Potential Resources in Livestock Feeds and Feeding Systems. In Theobroma Cacao-Deploying Science for Sustainability of Global Cocoa Economy. Intech Open.

Matthews, C., Crispie, F., Lewis, E., Reid, M., O’Toole, P. W., \& Cotter, P. D. (2019). The rumen microbiome: A crucial consideration when optimising milk and meat production and nitrogen utilisation efficiency. Gut microbes, 10(2), 115-132. doi.org/10.1080/19490976.2018.1505176

McCrickerd, K., \& Forde, C. G. (2016). Sensory influences on food intake control: Moving beyond palatability. Obesity Reviews, 17(1), 18-29. doi.org/10.1111/obr.12340

Melati, N. P. Y., Cakra, I. G. L. O., \& Partama, I. B. G. (2019). Pengaruh penggantian pollard dengan dedak padi yang disuplementasi multivitamin-mineral dalam konsentrat terhadap penampilan sapi Bali jantan. Majalah Ilmiah Peternakan 22, 5-9.

Mitruka, B. M., \& Rawnsley, H. M. (1977). Clinical biochemical and hematological reference values in normal experimental animals. Clinical biochemical and hematological reference values in normal experimental animals.

https://www.cabdirect.org/cabdirect/welcome/?targe $\mathrm{t}=\%$ 2fcabdirect $\% 2$ fabstract $\% 2 f 19782202260$

Natsir, A., Mujnisa, A., Mide, M. Z., Purnomo, N., \& Saade, M. F. (2018,). Initial assessment on the use of cocoa pulp in complete feed formulation: In vitro dry matter and organic matter digestibility. In IOP Conference Series: Earth and Environmental Science (157(1), 012013). IOP.

Publishing.https://iopscience.iop.org/article/10.1088 /1755-1315/157/1/012013/meta

Picard, M., McEwen, B. S., Epel, E. S., \& Sandi, C. (2018). An energetic view of stress: Focus on mitochondria. Frontiers in neuroendocrinology, 49, 72-85. doi.org/10.1016/j.yfrne.2018.01.001

Ramzinski, D. M., \& Weckerly, F. D. (2007). Scaling relationship between body weight and fermentation gut capacity in axis deer. Journal of Mammalogy, $88(2), 415-420$. doi.org/10.1644/06-MAMM-A-213R1.1

Rojo-Poveda, O., Barbosa-Pereira, L., Zeppa, G., \& Stévigny, C. (2020). Cocoa bean shell-A by-product with nutritional properties and biofunctional potential. Nutrients, 12, 1123. http://dx.doi.org/10.3390/nu12041123

Schwan, R. F., \& Wheals, A. E. (2004). The microbiology of cocoa fermentation and its role in chocolate quality. Critical reviews in food science and nutrition, 44(4), 205-221. doi.org/10.1080/10408690490464104
SCSAS. (2018). Development of Exports and Imports of South Sulawesi Province Commodity in 2019. Sulawesi, Indonesia, Sulawesi Central Statistics Agency of South. South Sulawesi Plantation Agency Increases Production of Ten Leading Commodities https://sulselprov.go.id/welcome/post/dinasperkebunan-sulsel-tingkatkan-produksi-sepuluhkomoditi-unggulan

Sejrsen, K., Hvelplund, T., \& Nielsen, M. O. (Eds.). (2006). Ruminant physiology: Digestion, metabolism and impact of nutrition on gene expression, immunology and stress. Wageningen Academic Publishers.

Slattery, B. (2005). Air Emissions from Animal Feeding Operations-Current Knowledge, Future Needs; National Research Council of the National Academies; The National Academic Press, Washington, DC, 2003, 286 pages, paperback, ISBN 0-309-08705-8 (US \$46). Agriculture, Ecosystems and Environment, 1(105), 445-446.

https://www.infona.pl/resource/bwmeta1.element.els evier-b07dd84d-d787-3553-a490-12c7896a9306

Suharti, S., Astuti, D. A., \& Wina, E. (2009). Kecernaan nutrien dan performa produksi sapi potong Peranakan Ongole (PO) yang diberi tepung lerak (Sapindus rarak) dalam ransum. JITV, 14(3), 200-207.

Suryanto, E., Bulkaini, S., \& Karda, I. W. (2017). Kualitas karkas, marbling, kolesterol daging dan komponen non karkas sapi Bali yang diberi pakan kulit buah kakao fermentasi. Bul Peternak, 41, 72. https://core.ac.uk/download/pdf/304207042.pdf

Syapridus, S., Rachmadi, D., \& Novita, C. I. (2016). Kecernaan in Vivo Bahan Kering Sapi Lokal Jantan yang Diberikan Pakan Fermentasi Kulit Coklat dan Ampas Tebu. Journal Ilmiah Mahasiswa Pertanian, 1(1). http://www.jim.unsyiah.ac.id/JFP/article/view/1237

Tahuk, P. K., Budhi, S. P. S., Panjono, P., \& Baliarti, E. (2018). Nitrogen balance, microbial protein synthesis and blood metabolites in fattening of male Bali cattle fed ration with different protein levels in smallholder farms. Journal of Indonesian Tropical Animal Agriculture, 43(1), 43-53. doi.org/10.14710/jitaa.43.1.43-53

Utama, I. H. (2001). Karakteristik anemia sapi Bali. Journal Veterinary 2, 13-16. https://ojs.unud.ac.id/index.php/jvet/article/view/22901

Xie, C., Duan, X., Long, C., \& Wu, X. (2020) Hepatic lipid metabolism is affected by a daily 3-meal pattern with varying dietary crude protein with a pig model. Animal Nutrition, 6(1), 16-23. doi.org/10.1016/j.aninu.2019.11.001

Zain, M. (2009). Substitusi rumput lapangan dengan kulit buah coklat amoniasi dalam ransum domba lokal. Media Peternakan, 32(1).

https://jurnal.ipb.ac.id/index.php/mediapeternakan /article/view/1157 